\title{
Review
}

\section{The Role of TRPA1 in Skin Physiology and Pathology}

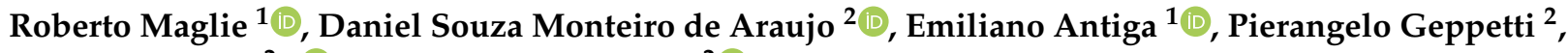 \\ Romina Nassini ${ }^{2, *(D)}$ and Francesco De Logu ${ }^{2}$ (D) \\ 1 Department of Health Sciences, Section of Dermatology, University of Florence, 50139 Florence, Italy; \\ roberto.maglie@unifi.it (R.M.); emiliano.antiga@unifi.it (E.A.) \\ 2 Department of Health Sciences, Clinical Pharmacology Unit, University of Florence, 50139 Florence, Italy; \\ daniel.souzamonteirodearaujo@unifi.it (D.S.M.d.A.); pierangelo.geppetti@unifi.it (P.G.); \\ francesco.delogu@unifi.it (F.D.L.) \\ * Correspondence: romina.nassini@unifi.it
}

check for updates

Citation: Maglie, R.; Souza Monteiro de Araujo, D.; Antiga, E.; Geppetti, P.; Nassini, R.; De Logu, F. The Role of TRPA1 in Skin Physiology and Pathology. Int. J. Mol. Sci. 2021, 22, 3065. https://doi.org/10.3390/ ijms22063065

Academic Editor: Viktorie Vlachova

Received: 4 March 2021

Accepted: 15 March 2021

Published: 17 March 2021

Publisher's Note: MDPI stays neutral with regard to jurisdictional claims in published maps and institutional affiliations.

Copyright: (c) 2021 by the authors. Licensee MDPI, Basel, Switzerland. This article is an open access article distributed under the terms and conditions of the Creative Commons Attribution (CC BY) license (https:/ / creativecommons.org/licenses/by/ $4.0 /)$.

\begin{abstract}
The transient receptor potential ankyrin 1 (TRPA1), a member of the TRP superfamily of channels, acts as 'polymodal cellular sensor' on primary sensory neurons where it mediates the peripheral and central processing of pain, itch, and thermal sensation. However, the TRPA1 expression extends far beyond the sensory nerves. In recent years, much attention has been paid to its expression and function in non-neuronal cell types including skin cells, such as keratinocytes, melanocytes, mast cells, dendritic cells, and endothelial cells. TRPA1 seems critically involved in a series of physiological skin functions, including formation and maintenance of physico-chemical skin barriers, skin cells, and tissue growth and differentiation. TRPA1 appears to be implicated in mechanistic processes in various immunological inflammatory diseases and cancers of the skin, such as atopic and allergic contact dermatitis, psoriasis, bullous pemphigoid, cutaneous T-cell lymphoma, and melanoma. Here, we report recent findings on the implication of TRPA1 in skin physiology and pathophysiology. The potential use of TRPA1 antagonists in the treatment of inflammatory and immunological skin disorders will be also addressed.
\end{abstract}

Keywords: TRPA1; TRP channel; skin disease; itch; ion channel; dermatophatology

\section{Introduction}

Transient receptor potential (TRP) channels are polymodal cation channels primarily permeable to calcium, which work as cellular sensors implicated in many physiological functions, ranging from pure sensory activities, such as nociception and temperature sensation, and homeostatic functions, such as osmoregulation, to many other functions, such as muscle contraction and vasomotor control [1]. In mammals, the superfamily of TRP channels encompasses 28 members [1], behaving as non-selective cation permeable channels, and classified into six subfamilies: The canonical or classic (TRPC1-7), vanilloid (TRPV1-6), melastatin (TRPM1-8), long TRP ankyrin (a solitary member is the transmembrane protein 1 [TRPA1]), and the more distant relatives, polycystins (TRPP1-5) and mucolipins (TRPML1-3) [1-3]. TRPs are expressed in a wide variety of both excitable and non-excitable cells [4-10]. Most TRPs have been localized to the plasma membrane where they nonselectively allow the influx of extracellular cations [11]. However, their presence has been documented in cellular organelles, with a pivotal role in establishing/maintaining vesicular calcium homeostasis and in regulating membrane trafficking [12]. TRPs are considered unique polymodal cell sensors, as their gating is directly operated by a plethora of exogenous and endogenous physical stimuli and chemical mediators or by changes in the intracellular environment [13]. As several TRPs localized in a subset of primary sensory neurons, they result as highly implicated in sensing physiological and noxious agents and more generally in nociceptive stimuli perception in a variety of tissues and organs, including the skin $[14,15]$. 
Emerging evidence suggests that multiple TRPs are involved in the regulation of the cutaneous functions. Apart from their prominent expression and role in nociceptive neurons, where they mediate the peripheral and central processing of pain, itch, and thermal sensation [16-20], some TRPs are found in non-neuronal cells [4,5,7] including skin cells $[6,21-23]$, where they are critically involved in formation and maintenance of physicochemical skin barriers, skin cells, and organ growth and differentiation, and cutaneous immunological and inflammatory processes. This review focuses on the functional role of TRPA1 in various cutaneous functions both under physiological and pathophysiological conditions.

\section{TRPA1 in Skin Physiology}

\subsection{Cutaneous Nerve Fibers and Neurogenic Inflammation}

The skin-localized sensory afferents are involved in the neuronal processing of multiple sensory modalities. A $\beta$-fibers with thickly myelinated axons, thus fast conduction velocities and low activation thresholds, are the predominant class of fibers responsible for sensing light touch. A subpopulation of C-fibers is responsible for gentle touch and light forces similar to A $\beta$-fibers [24-26]. Similar low-threshold A $\delta$-fiber responses have been observed in humans, but it remains to be determined if these fibers also influence touch perception [27]. The perception of acute noxious or painful touch are typically derived from the activation of high-threshold unmyelinated C-fibers and thinly myelinated $\mathrm{A} \delta$-fibers.

A specific subset of $\mathrm{C}$-fiber and $\mathrm{A} \delta$ - fiber nociceptors is exclusively sensitive to the selective TRPV1 agonist, capsaicin, the pungent ingredient in hot chili peppers, and thereby defined as 'capsaicin-sensitive' sensory neurons. TRPV1-expressing neurons comprise a subgroup of neurons defined as peptidergic because of their ability to produce neuropeptides, including the calcitonin gene-related peptide (CGRP) and tachykinins, such as substance P (SP) and neurokinin A (NKA) [28,29], which upon peripheral release, cause inflammatory responses, collectively referred to as "neurogenic inflammation" [28,29]. TRPA1 is present in $30-50 \%$ of TRPV1-expressing neurons and rarely exists in neurons which do not express TRPV1 [30].

The most prominent feature of the TRPA1 resides in its unique sensitivity for several exogenous and endogenous agonists which, based on their structure, activate the channel covalently, or modulate its activity in a different way. A number of naturally occurring TRPA1 agonists mainly found in alimentary sources include herbs and spices, such as cinnamaldehyde, contained in the cinnamon oil extracted from the Cinnamomum [31], several isothiocyanate compounds, such as allyl or benzyl isothiocyanate contained in mustard oil or wasabi, obtained from the Brassica seeds [32], and allicin and diallyl disulfide, contained in garlic (Allium sativum) [33]. Other rather heterogenous substances qualified as TRPA1 channel stimulants include volatile irritants, such as acrolein and crotonaldehyde [34,35], chemicals of industrial origin, [36-38], general anesthetics (e.g., isoflurane [39], lidocaine [40], propofol [41]), and laboratory chemicals (e.g., formalin [42-44]). Additional aldehydes which stimulate TRPA1 are formaldehyde [45], acetaldehyde [46] and crotonaldehyde [35,47] (all contained in cigarette smoke). These compounds, share a reactive chemical structure which enables them to covalently modify specific cysteine residues located within the cytoplasmic N-terminal region of the protein [48], resulting in TRPA1 activation. These features justify the large use of these compounds to better understand the mechanism of action and the role of the channel.

Non-reactive compounds which are unable to modify the channel covalently include compounds from plant origin, such as menthol [49], thymol, and carvacrol [50,51]. The non-electrophilic component contained in Cannabis sativa, delta-9-tetrahydrocannabinol (THC), also activates the TRPA1 channel without producing any covalent modification [52]. Different medicines or their metabolites such as clotrimazole [53], nifedipine [54], and non-steroidal anti-inflammatory drugs, such as diclofenac [55] and acyl-glucuronide ibuprofen [56], represent an additional subgroup of exogenous TRPA1 activators. 
The last ten years have witnessed a series of discoveries that have placed the TRPA1 channel as a major sensor of oxidative, nitrative, and carbonylic stress for the peripheral nervous system. Reactive oxygen (ROS), nitrative (RNS), and carbonylic (RCS) species have shown the ability to gate TRPA1 on peripheral terminals primary sensory neurons, thereby signaling pain, and neurogenic inflammation. ROS activate TRPA1 through a cysteine oxidation or disulfide formation [57], whereas RNS activate the channel through a S-nitrosylation reaction [57].

Among ROS, TRPA1 activators comprise hydrogen peroxide $\left(\mathrm{H}_{2} \mathrm{O}_{2}\right)[37,39,58]$, hypochlorite $\left(\mathrm{OCl}^{-}\right)$, superoxide $\left(\mathrm{O}^{2-}\right)$ [38]. Among RNS, NO [39,59,60], and peroxynitrite [39] are TRPA1 agonists. Metabolites generated by peroxidation or nitrosylation of plasma membrane phospholipids, including 4-hydroxynonenal (4-HNE), 4-hydroxyhexenal (4-HHE), 4-oxo-2-nonenal (4-ONE), and nitrooleic acid (9-OA- $\mathrm{NO}_{2}$ ) activate TRPA1 channels $[37,48,61-63]$. During inflammation cyclooxygenase induction and activation result in the release of proinflammatory and proalgesic prostaglandings and isoprostanes, which via a non-enzymatic dehydration generate cyclopentenone prostaglandin and isoprostane including 15-deoxy- $\Delta 12,14-\mathrm{PGJ}_{2}\left(15-\mathrm{d}-\mathrm{PGJ}_{2}\right), \mathrm{PGA}_{2}$ and $\mathrm{PGA}_{1}$, and 8-isoprostane-PGA 2 are formed. Cyclopentenone PGs and iso-PGs have been recognized as TRPA1 activators $[64,65]$. Finally, among the endogenously produced mediators, the malodourous gas hydrogen sulfide $\left(\mathrm{H}_{2} \mathrm{~S}\right)$, produced by cysteine metabolism and endowed with vasodilatatory and other properties [66], has also been identified as a TRPA1 stimulant [67].

\subsection{Keratinocytes Differentiation, Proliferation and Barrier Function}

Growing evidence has revealed that TRPs are actively involved in the regulation of skin physiology [68-77]. TRPV1 expression has been identified in epidermal and hair follicle keratinocytes, dermal mast cells, sebaceous gland-derived sebocytes, and dendritic cells $[78,79]$, which suggest functional roles in homeostatic and 'sensory' functions not limited to cutaneous nerve fibers. TRPV2 has been found in keratinocytes [80] and macrophages [81], and TRPV3 in blood vessels [7] and keratinocytes [82]. The presence of TRPV4 has been reported in basal and suprabasal keratinocytes of healthy human skin $[22,73]$. Finally, TRPA1 has been found in keratinocytes, melanocytes, and fibroblasts [6,23] (Figure 1).
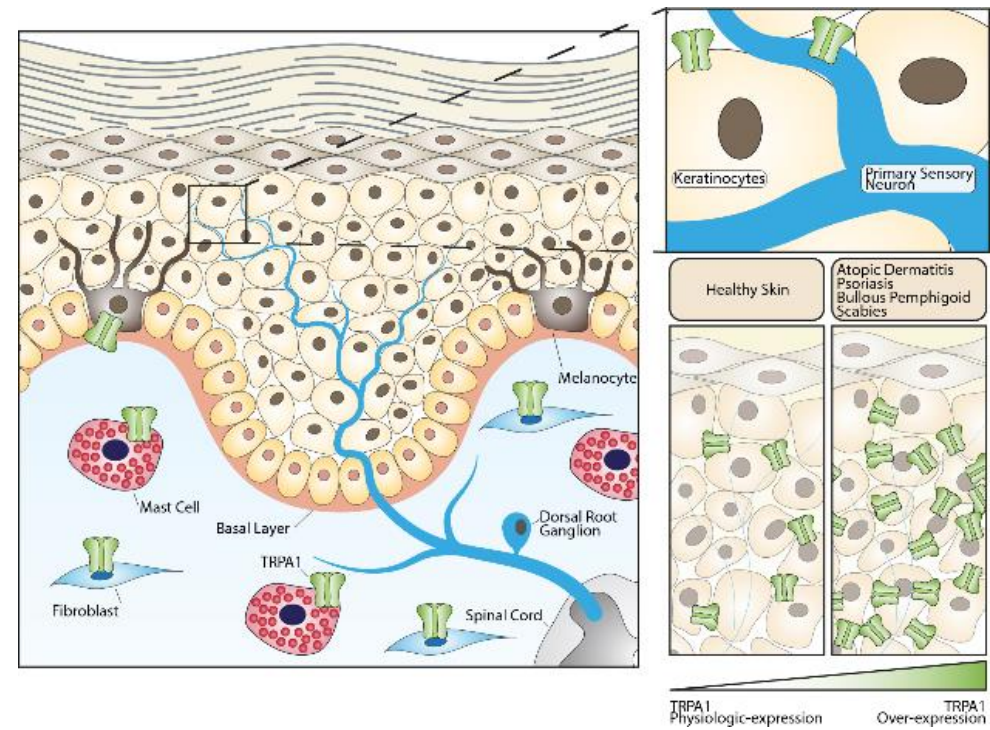

Figure 1. Role of the TRPA1 channel in skin homeostasis and skin diseases. TRPA1 channels expressed in sensory fibers innervating the skin or in different non-neuronal cells can either contribute to maintaining normal skin physiology or play important roles in the pathogenesis of skin diseases. 
In human skin, immunoreactivity for the TRPA1 channel has been detected in both keratinocytes and melanocytes [6]. It was also observed that the treatment of keratinocytes with icilin, a selective TRPA1 agonist, increased the expression of genes involved in cellular adhesion and extracellular matrix protein synthesis [6].

The production of the stratum corneum is one of the main roles of epidermal keratinocytes. Some studies showed that the administration of TRPA1 activators as well as the application of cold stimuli to the skin of mice, in which the epidermal barrier was mechanically disrupted, accelerated the rate of barrier regeneration [83]. Conversely, the application of a TRPA1 antagonist prevented the beneficial effects and markedly delayed the barrier healing [83]. Moreover, cold-induced TRPA1 activation resulted in a specific increase in intracellular calcium in human cultured epidermal keratinocytes, much higher than that observed in dorsal root ganglion cells [84], thus revealing that epidermis might be more sensitive to low temperature than the peripheral nervous system, and TRPA1 expressed in keratinocytes may have a central role in thermo-sensation of the skin [85]. Despite at low levels, TRPA1 mRNA was recently detected in mouse keratinocytes, where its selective deletion caused a marked deficit in mechanically-evoked ATP release, highlighting a possible involvement of keratinocytes in mechano-transduction [86]. Collectively, these findings suggest a "constitutively active" role for TRPA1 in the epidermal barrier homeostasis. TRPA1 is activated by ultraviolet radiation (UVR) in melanocytes, where its activation by UVR non-detrimental doses results in an early melanin synthesis [23]. However, additional TRPs may contribute to the formation and maintenance of the skin barrier [87], participate in the differentiation and growth of the skin cells [88], and ensure immunological properties during inflammatory processes [88], as TRPV4 activation has been involved in cell survival mechanisms after skin exposure to noxious heat.

\section{TRPA1 in Skin Diseases}

\subsection{Atopic Dermatitis and Allergic Contact Dermatitis}

Atopic dermatitis (AD) and allergic contact dermatitis (ACD) are common inflammatory skin diseases characterized by skin barrier disruption and an inflammatory response dominated by T helper 2 (Th2) cells and related products, such as interleukin (IL)-4, IL-5, and IL-13 [89,90]. Pruritus, which is characteristically histamine-independent, represents the most troublesome symptom of both diseases, resulting in a significantly impaired patient's quality of life.

TRPA1 contributes to the pathogenesis of chronic [91] and acute histamine-independent pruritus, such as those evoked in mice by injection of chloroquine [92] and the proenkephalin product, BAM8-22 [92-94]. In either human or murine AD models, TRPA1 has been shown to be significantly over-expressed by several cell types, including keratinocytes, mast cells, and dermal sensory nerve afferents [91]. TRPA1 expression was also enhanced in cell bodies of dorsal root ganglion (DRG) neurons from AD-mice [91]. In comparison, animal models of ACD revealed an over-expression of TRPA1 only on DRG neuronal cells, while no increased channel expression has been observed in non-neuronal skin cells [95].

A TRPA1-dependent pathway of itch in AD has been firstly identified by using a murine model of the disease induced by IL-13 [91]. In this study, IL-13 caused a chronic AD disease in mice characterized by an intensive chronic itch and increased expression of TRPA1 in mast cells, dermal sensory nerve fibers, and cell bodies of DRG neurons. Interestingly, mast cells recruited by IL-13 and localized in close proximity with TRPA1+ dermal afferents promoted a TRPA1-mediated local secretion of neuropeptides. In addition, pharmacological TRPA1 blockade selectively attenuated the itch-evoked scratching. Genetic deletion of mast cells in these mice led to significant reduction in the itch-scratching behaviors and lowered the TRPA1 expression in dermal neuropeptide containing afferent fibers [91]. Altogether, these data reveal a complex interaction among TRPA1+ dermal afferent nerves and TRPA1+ mast cells in the Th2-mediated inflammatory milieu underlying chronic itch in AD [91] (Figure 1). 
An additional study revealed that in a different murine model of AD induced by 2,4-dinitrochlorobenzene (DNCB), genetic deletion of TRPA1 attenuated pathological findings of $\mathrm{AD}$, including ear thickness, epidermal hyperplasia and pruritus, and dermal infiltration by mast cells, Th2 cytokines, and macrophages [96]. Moreover, DNCB, capable of inducing ACD in exposed humans, has been shown to directly and dose-dependently activate TRPA1 [97]. Likewise, in a murine model of ACD induced by topical application of oxazolone [95], TRPA1 deficiency correlated with milder ACD symptoms including pruritus, and lower levels of inflammatory cytokines and T-cell activation. More intriguingly, oxazolone has been shown to directly activate TRPA1, resulting in enhanced release of mediators of neurogenic inflammation and pruritus, including 5-hydroxytryptamine (5-HT), SP, and NKA. In addition, the absence of TRPA1 reduced the number of SP-responsive neurons, which are involved in the central transmission of pain and itch sensations. Similar results were obtained using a mouse model of ACD induced by urushiol, the poison ivy allergen [95]. Recently, in an oxazolone-induced murine model of ACD, the topical application of tacrolimus induced a persistent up-regulation of TRPA1 in DRG neurons and contributed to development of itch, thus explaining the pruritus and stinging sensation produced by the drug in humans [98]. Induction of skin dryness in mice has been associated with TRPA1 activation, that also correlated with changes in the gene expression profile driving to skin hyperplasia and lichenification [99].

In chronic allergic itch, multiple pathways of TRPA1 activation have been shown. These include a keratinocyte-neuron axis based on the release of thymic stromal lymphopoietin [100] and periostin [101], two AD-associated cytokines directly released by keratinocytes, and a Th2-cell-neuronal pathway based on the release of the pruritogenic cytokine IL-31 [102]. Although these studies suggest a role of TRPA and many channel ligands have been studied, yet TRPA1 blockers remain to be used clinically as anti-itch drugs. Off-target effects are a risk for TRPA1 ligands, given TRPA1 broad expression in different neuronal and non-neuronal cellular districts, which encompasses different biological functions. For this reason, the development of such drugs should proceed with caution. Nevertheless, since evidence showed that the TRPA1 is crucially involved in the pathogenesis of $\mathrm{AD}$ and $\mathrm{ACD}$, the pharmacological inhibition of the channel could be a valuable complementary strategy for local control of skin inflammation and pruritus observed in both diseases.

\subsection{Psoriasis}

Psoriasis is a common chronic inflammatory skin disease, characterized by erythema, skin thickness, and scaling [103]. Pruritus is observed in $60-90 \%$ of the patients [104]. Emerging evidence has highlighted a contribution of nociceptive sensory nerve endings in the pathogenesis of psoriasis, with a multi-faced role in detecting noxious stimuli, promoting the activation of immune cells and modulating the immune microenvironment [105]. Of note, different studies showed increased C-fiber innervation in the epidermis of psoriatic skin lesions [106-110]. The altered quantity of nerve fibers was associated with the increased expression of neuropeptides including SP and CGRP in psoriasis epidermal tissue $[108,111]$. Elevated neuropeptide content in the plasma of patients with psoriasis also correlated with psoriasis severity index scores [112]. Moreover, cutaneous denervation induces a reduction of skin inflammation in psoriasis patients and in mice with psoriasiform dermatitis [113].

More recently, the role of TRPA 1 in psoriasis has been explored. It was originally reported that in a murine model of imiquimod (IMQ)-induced psoriasis-like lesions, topical application of the drug was associated with elevated expression of TRPA1 in affected skin areas [114]. Similar results were obtained in psoriatic skin from human subjects where TRPA1 and TRPV1 genes were over-expressed [115]. Mechanistic studies provided contrasting results on the role of TRPA1 in murine models of psoriasis. Pharmacological blockade or genetic deletion of TRPA1 could, in fact, worsen psoriasis dermatitis and nocifensive and itch behavior in mice, thus suggesting a protective role for TRPA1 in psoriasis [116]. 
At the molecular level, the pathology in TRPA1 deleted mice was characterized by higher levels of inflammatory cytokines, including IL- $1 \beta, \mathrm{TNF}-\alpha$, and IL-22 compared to wild-type mice [116]. The protective role for TRPA1 in psoriasis was strengthened by the observation that a 3-weeks treatment with dry food containing mustard seed (5\%) reduced IMQ inflammation in mice [117]. Conversely, another study reported that TRPA1 genetic deletion sustained the dermal inflammation and the Th17-related cytokines expression in a severe model of IMQ-induced psoriasis, which also induced a systemic inflammatory reaction in mice [114]. As TRPA1 is expressed by primary sensory neurons, keratinocytes, and immune cells, we can speculate that channel function is affected by the immune environment. Collectively, these data suggested that TRPA1 activation or inhibition may simultaneously act in a protective manner in psoriasis, arguably by regulation of the activity of TRPV1 (Figure 1).

\subsection{Cutaneous T-Cell Lymphoma}

Cutaneous T-cell lymphomas (CTCL) are a heterogeneous group of primary cutaneous lympho-proliferative disorders, including mycosis fungoides (MF) and Sézary syndrome (SS) as the most common clinical presentations [118]. Pruritus is a debilitating symptom in patients with MF and SS [118]. In these patients, the shift to Th2-type immunity, with neoplastic cells producing enhanced Th2-associated cytokines, including IL-4 and IL-31, partly explains the severity of pruritus $[119,120]$. However, a recent study reported TRPA1 as a critical mediator involved in CTCL-associated itch [121]. Recent data showed that miR711, released by neoplastic skin-resident T-cells, induced TRPA1-dependent itch in mice by direct TRPA1 activation [121]. Interestingly, the itching activity of miR-711 was mediated by a short and evolutionary conserved core sequence that was both necessary and sufficient for the TRPA1 gating. In addition, in contrast with conventional TRPA1 agonists, miR-711 did not homogeneously elicit pain, itch, and neurogenic inflammation [121]. Such diversity was ascribed to a different binding domain in the extracellular portion of the protein, a shorter opening time of TRPA1, and the ensuing lower calcium permeability or the activation of different nerve terminals afferents, which encode diverse sensory modalities. Finally, inhibition of miR-711 activity with an extracellular complementary sequence or disruption of the miR-711/TRPA1 interaction with a blocking peptide significantly attenuated the scratching behavior in a mouse model of CTCL. Collectively, these data revealed an unconventional role of extracellular miRNAs as itch mediators and TRPA1 modulators and confirmed the biological relevance of this interaction in the pathophysiology of CTCLassociated itch.

\subsection{Other Pruritic Skin or Systemic Diseases}

Chronic histamine-independent pruritus occurs in a wide variety of other cutaneous and systemic diseases. A common skin disease characterized by pruritus is scabies, a contagious parasitic infestation caused by the mite Sarcoptes scabiei hominis [122]. In the skin of patients with scabies, non-histaminergic itching receptors, including TRPA1, TRPV1, and the protease-activated receptor 2 (PAR2), have been found to be over-expressed [123]. Interestingly, increased PAR2 expression was associated with increased tryptase+ cells and reduced histamine+ cells near the dermal-epidermal junction, potentially suggesting a TRPA1/mast cell pathway similar to that previously reported in AD [123] (Figure 1).

A common systemic cause of itch is that related to liver dysfunction, which in turn causes an elevation of circulating bile acids (BA). Remarkably, one study reported the coexpression of the G-protein-coupled BA receptor 1 (TGR5) and TRPA1 in cutaneous afferent neurons in mice [124]. TRG5 activation by BA sensitized TRPA1 via enhanced intracellular signaling through $\mathrm{G} \beta \gamma$, protein kinase $\mathrm{C}$, and calcium in vitro. In mice over-expressing TRG5, the exacerbated spontaneous scratching behavior was reduced by TRPA1 antagonists, thus supporting a coactivation of TGR5 and TRPA1 in BA induced pruritus [124].

A study reported TRPA1 over-expression in the epidermis of patients with bullous pemphigoid, a rare autoantibody-mediated blistering disease characterized by intense 
pruritus, compared to healthy skin, but channel expression did not significantly correlate, neither with eosinophil dermal infiltration nor with the severity of pruritus [125] (Figure 1).

Finally, a distinctive cause of pruritus induced by physical factors is that following burn injuries. Recently, one study revealed that mRNA levels of TRPA1 as well as TRPV4 were increased in the skin of itching burn scars [126]. However, further studies are needed to identify the role of TRPA1 in burn-associated itch.

\section{Therapeutic Perspectives and Future Directions}

The hypothesis that TRPA1 is implicated in chronic neuropathic [9,10,127-129], inflammatory [129,130], migraine [131,132], and cancer pain [133] is robustly supported. In contrast, current understanding of the pathophysiological roles of TRPA1 in the skin needs further investigations.

Here we showed that TRPA1 may exert a number of functions in different physiological and pathological skin processes. Increasing evidence indicates a major role of TRPA1 in histamine-independent itch occurring in chronic inflammatory skin diseases such as AD, liver dysfunction, or neoplastic diseases, such as cutaneous T-cell lymphoma, thus making these conditions suitable areas of investigation for drugs that target TRPA1. Among the various TRPA1 antagonists that have shown selectivity toward TRPA1, only five have been tested in clinical trials for the treatment of pain or other conditions (e.g., allergic asthma) [134-138].

A recent review identified 28 patent applications for TRPA1 antagonists from 2015 to 2019. Among them, some have been successfully tested in pre-clinical models of skin diseases such atopic dermatitis [139]. In contrast, none have entered large clinical trials for the treatment of skin diseases in humans. A thorough review of registered clinical trials (www.clinicaltrial.gov) using the key words "TRPA1 and skin" or "TRPA1 and pruritus" finds only one study on the effects of L-menthol, a substance that does not directly target TRPA1, as a topical counter-irritant on cutaneous pain and hyperalgesia provoked by topical application of the TRPA1-agonist trans-cinnamaldehyde in healthy human volunteers. Despite robust evidence of TRPA1 involvement in pruritic skin diseases, reasons explaining the delay in translating TRPA1 antagonists from the pre-clinical to the clinical setting, remain unclear. However, other therapeutic strategies are worth exploring.

It is noteworthy that multiple molecules can selectively activate TRPA1 inducing long-lasting desensitization of the channel. Crotalphine has been shown to inhibit a chemically induced inflammatory hypersensitivity in mice via the desensitization of TRPA1peptidergic nerve endings [140]. In allergic rhinitis, a disease sharing some pathological features with $\mathrm{AD}$ and $\mathrm{ACD}$, a combination of azelastine hydrochloride and fluticasone propionate has been shown to induce desensitization of TRPA1 and TRPV1 expressing sensory neurons, thus ameliorating local airway inflammation [141]. Finally, after the exposure to isopetasin, extracts from the butterbur plant (Petasites hybridus), and parthenolide, a major constituent of Tanacetum parthenium, TRPA1 channel and the TRPA1 expressing neurons undergo to a dose-dependent neuronal desensitization which may account for the relief of pain and neurogenic inflammation of the two plant extracts [142,143].

TRPA1 remains a field of active investigation for other skin conditions. For example, TRPA1 proteins have been found in melanoma cell lines [144-146], but the role of TRPA1 in melanoma in vivo remains far less clear. TRPA1 is of paramount importance to signal pain associated with skin cancers or related therapies, including dacarbazine-induced pain in melanoma [147], or pain associated with photodynamic therapy used for the treatment of non-melanoma skin cancer [148]. Likewise, it may be intriguing to explore TRPA1 activity in pain associated with inflammatory or autoimmune skin diseases, such as pemphigus vulgaris [149].

Finally, increasing evidence supports a role for TRPA1 in fibrosis associated with systemic diseases $[150,151]$. Accordingly, the possibility that TRPA1 promotes fibrosis in fibrogenic skin diseases (e.g., scleroderma) or wound healing is worth investigating, due to the lack of effective therapeutic strategies in such conditions. 
Author Contributions: R.M., D.S.M.d.A., and F.D.L. created the outline and wrote the manuscript, and E.A., P.G., and R.N. revised the manuscript. All authors have read and agreed to the published version of the manuscript.

Funding: This research received no external funding.

Institutional Review Board Statement: Not applicable.

Informed Consent Statement: Not applicable.

Acknowledgments: Not applicable.

Conflicts of Interest: The authors declare no conflict of interest.

\section{References}

1. Clapham, D.E.; Runnels, L.W.; Strübing, C. The TRP ion channel family. Nat. Rev. Neurosci. 2001, 2, 387-396. [CrossRef] [PubMed]

2. Wu, L.J.; Sweet, T.B.; Clapham, D.E. International Union of Basic and Clinical Pharmacology. LXXVI. Current progress in the mammalian TRP ion channel family. Pharmacol. Rev. 2010, 62, 381-404. [CrossRef]

3. de Araujo, D.S.M.; Nassini, R.; Geppetti, P.; De Logu, F. TRPA1 as a therapeutic target for nociceptive pain. Expert Opin. Ther. Targets 2020, 24, 997-1008. [CrossRef] [PubMed]

4. Nassini, R.; Pedretti, P.; Moretto, N.; Fusi, C.; Carnini, C.; Facchinetti, F.; Viscomi, A.R.; Pisano, A.R.; Stokesberry, S.; Brunmark, C.; et al. Transient receptor potential ankyrin 1 channel localized to non-neuronal airway cells promotes non-neurogenic inflammation. PLoS ONE 2012, 7, e42454. [CrossRef] [PubMed]

5. Nozawa, K.; Kawabata-Shoda, E.; Doihara, H.; Kojima, R.; Okada, H.; Mochizuki, S.; Sano, Y.; Inamura, K.; Matsushime, H.; Koizumi, T.; et al. TRPA1 regulates gastrointestinal motility through serotonin release from enterochromaffin cells. Proc. Natl. Acad. Sci. USA 2009, 106, 3408-3413. [CrossRef]

6. Atoyan, R.; Shander, D.; Botchkareva, N.V. Non-neuronal expression of transient receptor potential type A1 (TRPA1) in human skin. J. Investig. Dermatol. 2009, 129, 2312-2315. [CrossRef] [PubMed]

7. Earley, S.; Gonzales, A.L.; Crnich, R. Endothelium-dependent cerebral artery dilation mediated by TRPA1 and Ca ${ }^{2+}$-Activated K ${ }^{+}$ channels. Circ. Res. 2009, 104, 987-994. [CrossRef] [PubMed]

8. Mukhopadhyay, I.; Gomes, P.; Aranake, S.; Shetty, M.; Karnik, P.; Damle, M.; Kuruganti, S.; Thorat, S.; Khairatkar-Joshi, N. Expression of functional TRPA1 receptor on human lung fibroblast and epithelial cells. J. Recept. Signal Transduct. Res. 2011, 31, 350-358. [CrossRef] [PubMed]

9. De Logu, F.; Li Puma, S.; Landini, L.; Portelli, F.; Innocenti, A.; de Araujo, D.S.M.; Janal, M.N.; Patacchini, R.; Bunnett, N.W.; Geppetti, P.; et al. Schwann cells expressing nociceptive channel TRPA1 orchestrate ethanol-evoked neuropathic pain in mice. J. Clin. Investig. 2019, 129, 5424-5441. [CrossRef] [PubMed]

10. De Logu, F.; Nassini, R.; Materazzi, S.; Carvalho Gonçalves, M.; Nosi, D.; Rossi Degl'Innocenti, D.; Marone, I.M.; Ferreira, J.; Li Puma, S.; Benemei, S.; et al. Schwann cell TRPA1 mediates neuroinflammation that sustains macrophage-dependent neuropathic pain in mice. Nat. Commun. 2017, 8, 1887. [CrossRef] [PubMed]

11. Owsianik, G.; Talavera, K.; Voets, T.; Nilius, B. Permeation and selectivity of TRP channels. Annu. Rev. Physiol. 2006, 68, 685-717. [CrossRef]

12. Froghi, S.; Grant, C.R.; Tandon, R.; Quaglia, A.; Davidson, B.; Fuller, B. New Insights on the Role of TRP Channels in Calcium Signalling and Immunomodulation: Review of Pathways and Implications for Clinical Practice. Clin. Rev. Allergy Immunol. 2021, 1-22. [CrossRef]

13. Ramsey, I.S.; Delling, M.; Clapham, D.E. An introduction to TRP channels. Annu. Rev. Physiol. 2006, 68, 619-647. [CrossRef] [PubMed]

14. De Logu, F.; Geppetti, P. Ion Channel Pharmacology for Pain Modulation. Handb. Exp. Pharmacol. 2019, 260, 161-186. [CrossRef] [PubMed]

15. Vriens, J.; Watanabe, H.; Janssens, A.; Droogmans, G.; Voets, T.; Nilius, B. Cell swelling, heat, and chemical agonists use distinct pathways for the activation of the cation channel TRPV4. Proc. Natl. Acad. Sci. USA 2004, 101, 396-401. [CrossRef] [PubMed]

16. Nilius, B.; Owsianik, G.; Voets, T.; Peters, J.A. Transient receptor potential cation channels in disease. Physiol. Rev. 2007, 87, 165-217. [CrossRef]

17. Akiyama, T.; Carstens, E. Neural processing of itch. Neuroscience 2013, 250, 697-714. [CrossRef]

18. Brederson, J.D.; Kym, P.R.; Szallasi, A. Targeting TRP channels for pain relief. Eur. J. Pharmacol. 2013, 716, 61-76. [CrossRef]

19. Lucaciu, O.C.; Connell, G.P. Itch sensation through transient receptor potential channels: A systematic review and relevance to manual therapy. J. Manip. Physiol. Ther. 2013, 36, 385-393. [CrossRef] [PubMed]

20. Tóth, B.I.; Bíró, T. TRP Channels and Pruritus. Open Pain J. 2013, 6, 62-80. [CrossRef]

21. Sokabe, T.; Tominaga, M. The TRPV4 cation channel: A molecule linking skin temperature and barrier function. Commun. Integr. Biol. 2010, 3, 619-621. [CrossRef]

22. Radtke, C.; Sinis, N.; Sauter, M.; Jahn, S.; Kraushaar, U.; Guenther, E.; Rodemann, H.P.; Rennekampff, H.O. TRPV channel expression in human skin and possible role in thermally induced cell death. J. Burn Care Res. 2011, 32, 150-159. [CrossRef] 
23. Bellono, N.W.; Kammel, L.G.; Zimmerman, A.L.; Oancea, E. UV light phototransduction activates transient receptor potential A1 ion channels in human melanocytes. Proc. Natl. Acad. Sci. USA 2013, 110, 2383-2388. [CrossRef] [PubMed]

24. Moehring, F.; Halder, P.; Seal, R.P.; Stucky, C.L. Uncovering the Cells and Circuits of Touch in Normal and Pathological Settings. Neuron 2018, 100, 349-360. [CrossRef] [PubMed]

25. Liljencrantz, J.; Olausson, $\mathrm{H}$. Tactile $\mathrm{C}$ fibers and their contributions to pleasant sensations and to tactile allodynia. Front. Behav. Neurosci. 2014, 8, 37. [CrossRef]

26. Vallbo, A.B.; Olausson, H.; Wessberg, J. Unmyelinated afferents constitute a second system coding tactile stimuli of the human hairy skin. J. Neurophysiol. 1999, 81, 2753-2763. [CrossRef]

27. Adriaensen, H.; Gybels, J.; Handwerker, H.O.; Van Hees, J. Response properties of thin myelinated (A-delta) fibers in human skin nerves. J. Neurophysiol. 1983, 49, 111-122. [CrossRef] [PubMed]

28. Geppetti, P.; Holzer, P. Neurogenic Inflammation; CRC Press: Boca Raton, FL, USA, 1996; p. 324.

29. De Logu, F.; Landini, L.; Janal, M.N.; Li Puma, S.; De Cesaris, F.; Geppetti, P.; Nassini, R. Migraine-provoking substances evoke periorbital allodynia in mice. J. Headache Pain 2019, 20, 1-9. [CrossRef] [PubMed]

30. Kobayashi, K.; Fukuoka, T.; Obata, K.; Yamanaka, H.; Dai, Y.; Tokunaga, A.; Noguchi, K. Distinct expression of TRPM8, TRPA1, and TRPV1 mRNAs in rat primary afferent neurons with adelta/c-fibers and colocalization with trk receptors. J. Comp. Neurol. 2005, 493, 596-606. [CrossRef]

31. Bandell, M.; Story, G.M.; Hwang, S.W.; Viswanath, V.; Eid, S.R.; Petrus, M.J.; Earley, T.J.; Patapoutian, A. Noxious cold ion channel TRPA1 is activated by pungent compounds and bradykinin. Neuron 2004, 41, 849-857. [CrossRef]

32. Jordt, S.E.; Bautista, D.M.; Chuang, H.H.; McKemy, D.D.; Zygmunt, P.M.; Högestätt, E.D.; Meng, I.D.; Julius, D. Mustard oils and cannabinoids excite sensory nerve fibres through the TRP channel ANKTM1. Nature 2004, 427, 260-265. [CrossRef]

33. Bautista, D.M.; Movahed, P.; Hinman, A.; Axelsson, H.E.; Sterner, O.; Högestätt, E.D.; Julius, D.; Jordt, S.E.; Zygmunt, P.M. Pungent products from garlic activate the sensory ion channel TRPA1. Proc. Natl. Acad. Sci. USA 2005, 102, 12248-12252. [CrossRef] [PubMed]

34. Macpherson, L.J.; Geierstanger, B.H.; Viswanath, V.; Bandell, M.; Eid, S.R.; Hwang, S.; Patapoutian, A. The pungency of garlic: Activation of TRPA1 and TRPV1 in response to allicin. Curr. Biol. 2005, 15, 929-934. [CrossRef] [PubMed]

35. Andrè, E.; Campi, B.; Materazzi, S.; Trevisani, M.; Amadesi, S.; Massi, D.; Creminon, C.; Vaksman, N.; Nassini, R.; Civelli, M.; et al. Cigarette smoke-induced neurogenic inflammation is mediated by alpha,beta-unsaturated aldehydes and the TRPA1 receptor in rodents. J. Clin. Investig. 2008, 118, 2574-2582. [CrossRef] [PubMed]

36. Escalera, J.; von Hehn, C.A.; Bessac, B.F.; Sivula, M.; Jordt, S.E. TRPA1 mediates the noxious effects of natural sesquiterpene deterrents. J. Biol. Chem. 2008, 283, 24136-24144. [CrossRef]

37. Andersson, D.A.; Gentry, C.; Moss, S.; Bevan, S. Transient receptor potential A1 is a sensory receptor for multiple products of oxidative stress. J. Neurosci. 2008, 28, 2485-2494. [CrossRef] [PubMed]

38. Bessac, B.F.; Sivula, M.; von Hehn, C.A.; Escalera, J.; Cohn, L.; Jordt, S.E. TRPA1 is a major oxidant sensor in murine airway sensory neurons. J. Clin. Investig. 2008, 118, 1899-1910. [CrossRef]

39. Sawada, Y.; Hosokawa, H.; Matsumura, K.; Kobayashi, S. Activation of transient receptor potential ankyrin 1 by hydrogen peroxide. Eur. J. Neurosci. 2008, 27, 1131-1142. [CrossRef] [PubMed]

40. Matta, J.A.; Cornett, P.M.; Miyares, R.L.; Abe, K.; Sahibzada, N.; Ahern, G.P. General anesthetics activate a nociceptive ion channel to enhance pain and inflammation. Proc. Natl. Acad. Sci. USA 2008, 105, 8784-8789. [CrossRef] [PubMed]

41. Leffler, A.; Lattrell, A.; Kronewald, S.; Niedermirtl, F.; Nau, C. Activation of TRPA1 by membrane permeable local anesthetics. Mol. Pain 2011, 7, 1744-8069. [CrossRef] [PubMed]

42. Fischer, M.J.; Leffler, A.; Niedermirtl, F.; Kistner, K.; Eberhardt, M.; Reeh, P.W.; Nau, C. The general anesthetic propofol excites nociceptors by activating TRPV1 and TRPA1 rather than GABAA receptors. J. Biol. Chem. 2010, 285, 34781-34792. [CrossRef]

43. Fischer, M.; Carli, G.; Raboisson, P.; Reeh, P. The interphase of the formalin test. Pain 2014, 155, 511-521. [CrossRef] [PubMed]

44. Macpherson, L.J.; Xiao, B.; Kwan, K.Y.; Petrus, M.J.; Dubin, A.E.; Hwang, S.; Cravatt, B.; Corey, D.P.; Patapoutian, A. An ion channel essential for sensing chemical damage. J. Neurosci. 2007, 27, 11412-11415. [CrossRef]

45. McNamara, C.R.; Mandel-Brehm, J.; Bautista, D.M.; Siemens, J.; Deranian, K.L.; Zhao, M.; Hayward, N.J.; Chong, J.A.; Julius, D.; Moran, M.M.; et al. TRPA1 mediates formalin-induced pain. Proc. Natl. Acad. Sci. USA 2007, 104, 13525-13530. [CrossRef]

46. Bang, S.; Kim, K.Y.; Yoo, S.; Kim, Y.G.; Hwang, S.W. Transient receptor potential A1 mediates acetaldehyde-evoked pain sensation. Eur. J. Neurosci. 2007, 26, 2516-2523. [CrossRef]

47. Andrè, E.; Gatti, R.; Trevisani, M.; Preti, D.; Baraldi, P.G.; Patacchini, R.; Geppetti, P. Transient receptor potential ankyrin receptor 1 is a novel target for pro-tussive agents. Br. J. Pharmacol. 2009, 158, 1621-1628. [CrossRef] [PubMed]

48. Hinman, A.; Chuang, H.H.; Bautista, D.M.; Julius, D. TRP channel activation by reversible covalent modification. Proc. Natl. Acad. Sci. USA 2006, 103, 19564-19568. [CrossRef] [PubMed]

49. Cao, D.S.; Zhong, L.; Hsieh, T.H.; Abooj, M.; Bishnoi, M.; Hughes, L.; Premkumar, L.S. Expression of transient receptor potential ankyrin 1 (TRPA1) and its role in insulin release from rat pancreatic beta cells. PLoS ONE 2012, 7, e38005. [CrossRef]

50. Karashima, Y.; Damann, N.; Prenen, J.; Talavera, K.; Segal, A.; Voets, T.; Nilius, B. Bimodal action of menthol on the transient receptor potential channel TRPA1. J. Neurosci. 2007, 27, 9874-9884. [CrossRef] [PubMed]

51. Lee, S.P.; Buber, M.T.; Yang, Q.; Cerne, R.; Cortés, R.Y.; Sprous, D.G.; Bryant, R.W. Thymol and related alkyl phenols activate the hTRPA1 channel. Br. J. Pharmacol. 2008, 153, 1739-1749. [CrossRef] [PubMed] 
52. De Petrocellis, L.; Vellani, V.; Schiano-Moriello, A.; Marini, P.; Magherini, P.C.; Orlando, P.; Di Marzo, V. Plant-derived cannabinoids modulate the activity of transient receptor potential channels of ankyrin type-1 and melastatin type-8. J. Pharmacol. Exp. Ther. 2008, 325, 1007-1015. [CrossRef] [PubMed]

53. Meseguer, V.; Karashima, Y.; Talavera, K.; D’Hoedt, D.; Donovan-Rodríguez, T.; Viana, F.; Nilius, B.; Voets, T. Transient receptor potential channels in sensory neurons are targets of the antimycotic agent clotrimazole. J. Neurosci. 2008, 28, 576-586. [CrossRef] [PubMed]

54. Fajardo, O.; Meseguer, V.; Belmonte, C.; Viana, F. TRPA1 channels: Novel targets of 1,4-dihydropyridines. Channels 2008, 2, 429-438. [CrossRef] [PubMed]

55. Hu, H.; Tian, J.; Zhu, Y.; Wang, C.; Xiao, R.; Herz, J.M.; Wood, J.D.; Zhu, M.X. Activation of TRPA1 channels by fenamate nonsteroidal anti-inflammatory drugs. Pflug. Arch. 2010, 459, 579-592. [CrossRef]

56. De Logu, F.; Li Puma, S.; Landini, L.; Tuccinardi, T.; Poli, G.; Preti, D.; De Siena, G.; Patacchini, R.; Tsagareli, M.G.; Geppetti, P.; et al. The acyl-glucuronide metabolite of ibuprofen has analgesic and anti-inflammatory effects via the TRPA1 channel. Pharmacol. Res. 2019, 142, 127-139. [CrossRef] [PubMed]

57. Takahashi, N.; Mori, Y. TRP Channels as Sensors and Signal Integrators of Redox Status Changes. Front. Pharmacol. 2011, 2, 58. [CrossRef] [PubMed]

58. Bessac, B.F.; Sivula, M.; von Hehn, C.A.; Caceres, A.I.; Escalera, J.; Jordt, S.E. Transient receptor potential ankyrin 1 antagonists block the noxious effects of toxic industrial isocyanates and tear gases. FASEB J. 2009, 23, 1102-1114. [CrossRef] [PubMed]

59. Miyamoto, T.; Dubin, A.E.; Petrus, M.J.; Patapoutian, A. TRPV1 and TRPA1 mediate peripheral nitric oxide-induced nociception in mice. PLoS ONE 2009, 4, e7596. [CrossRef] [PubMed]

60. Takahashi, N.; Mizuno, Y.; Kozai, D.; Yamamoto, S.; Kiyonaka, S.; Shibata, T.; Uchida, K.; Mori, Y. Molecular characterization of TRPA1 channel activation by cysteine-reactive inflammatory mediators. Channels 2008, 2, 287-298. [CrossRef] [PubMed]

61. Trevisani, M.; Siemens, J.; Materazzi, S.; Bautista, D.M.; Nassini, R.; Campi, B.; Imamachi, N.; Andrè, E.; Patacchini, R.; Cottrell, G.S.; et al. 4-Hydroxynonenal, an endogenous aldehyde, causes pain and neurogenic inflammation through activation of the irritant receptor TRPA1. Proc. Natl. Acad. Sci. USA 2007, 104, 13519-13524. [CrossRef] [PubMed]

62. Taylor-Clark, T.E.; McAlexander, M.A.; Nassenstein, C.; Sheardown, S.A.; Wilson, S.; Thornton, J.; Carr, M.J.; Undem, B.J. Relative contributions of TRPA1 and TRPV1 channels in the activation of vagal bronchopulmonary C-fibres by the endogenous autacoid 4-oxononenal. J. Physiol. 2008, 586, 3447-3459. [CrossRef] [PubMed]

63. Taylor-Clark, T.E.; Ghatta, S.; Bettner, W.; Undem, B.J. Nitrooleic acid, an endogenous product of nitrative stress, activates nociceptive sensory nerves via the direct activation of TRPA1. Mol. Pharmacol. 2009, 75, 820-829. [CrossRef]

64. Taylor-Clark, T.E.; Undem, B.J.; Macglashan, D.W., Jr.; Ghatta, S.; Carr, M.J.; McAlexander, M.A. Prostaglandin-induced activation of nociceptive neurons via direct interaction with transient receptor potential A1 (TRPA1). Mol. Pharmacol. 2008, 73, $274-281$. [CrossRef] [PubMed]

65. Materazzi, S.; Nassini, R.; Andrè, E.; Campi, B.; Amadesi, S.; Trevisani, M.; Bunnett, N.W.; Patacchini, R.; Geppetti, P. Coxdependent fatty acid metabolites cause pain through activation of the irritant receptor TRPA1. Proc. Natl. Acad. Sci. USA 2008, 105, 12045-12050. [CrossRef] [PubMed]

66. Szabó, C. Hydrogen sulphide and its therapeutic potential. Nat. Rev. Drug Discov. 2007, 6, 917-935. [CrossRef] [PubMed]

67. Okubo, K.; Matsumura, M.; Kawaishi, Y.; Aoki, Y.; Matsunami, M.; Okawa, Y.; Sekiguchi, F.; Kawabata, A. Hydrogen sulfideinduced mechanical hyperalgesia and allodynia require activation of both Cav3.2 and TRPA1 channels in mice. Br. J. Pharmacol. 2012, 166, 1738-1743. [CrossRef]

68. Güler, A.D.; Lee, H.; Iida, T.; Shimizu, I.; Tominaga, M.; Caterina, M. Heat-evoked activation of the ion channel, TRPV4. J. Neurosci. 2002, 22, 6408-6414. [CrossRef] [PubMed]

69. Lee, S.H.; Tonello, R.; Im, S.T.; Jeon, H.; Park, J.; Ford, Z.; Davidson, S.; Kim, Y.H.; Park, C.K.; Berta, T. Resolvin D3 controls mouse and human TRPV1-positive neurons and preclinical progression of psoriasis. Theranostics 2020, 10, 12111-12126. [CrossRef]

70. Fujii, N.; Kenny, G.P.; McGarr, G.W.; Amano, T.; Honda, Y.; Kondo, N.; Nishiyasu, T. TRPV4 channel blockade does not modulate skin vasodilation and sweating during hyperthermia or cutaneous post-occlusive reactive and thermal hyperemia. Am. J. Physiol. Regul. Integr. Comp. Physiol. 2020. [CrossRef] [PubMed]

71. Weyer-Menkhoff, I.; Pinter, A.; Schlierbach, H.; Schänzer, A.; Lötsch, J. Epidermal expression of human TRPM8, but not of TRPA1 ion channels, is associated with sensory responses to local skin cooling. Pain 2019, 160, 2699-2709. [CrossRef]

72. Cai, S.; Fatherazi, S.; Presland, R.B.; Belton, C.M.; Izutsu, K.T. TRPC channel expression during calcium-induced differentiation of human gingival keratinocytes. J. Dermatol. Sci. 2005, 40, 21-28. [CrossRef] [PubMed]

73. Chung, M.K.; Lee, H.; Caterina, M.J. Warm temperatures activate TRPV4 in mouse 308 keratinocytes. J. Biol. Chem. 2003, 278, 32037-32046. [CrossRef]

74. Peier, A.M.; Reeve, A.J.; Andersson, D.A.; Moqrich, A.; Earley, T.J.; Hergarden, A.C.; Story, G.M.; Colley, S.; Hogenesch, J.B.; McIntyre, P.; et al. A heat-sensitive TRP channel expressed in keratinocytes. Science 2002, 296, 2046-2049. [CrossRef]

75. Lehen'kyi, V.; Beck, B.; Polakowska, R.; Charveron, M.; Bordat, P.; Skryma, R.; Prevarskaya, N. TRPV6 is a Ca2+ entry channel essential for Ca2+-induced differentiation of human keratinocytes. J. Biol. Chem. 2007, 282, 22582-22591. [CrossRef] [PubMed]

76. Kwan, K.Y.; Glazer, J.M.; Corey, D.P.; Rice, F.L.; Stucky, C.L. TRPA1 modulates mechanotransduction in cutaneous sensory neurons. J. Neurosci. 2009, 29, 4808-4819. [CrossRef] [PubMed] 
77. Yang, P.; Feng, J.; Luo, J.; Madison, M.; Hu, H. Frontiers in Neuroscience A Critical Role for TRP Channels in the Skin. In Neurobiology of TRP Channels; Emir, T.L.R., Ed.; CRC Press/Taylor \& Franci LLC.: Boca Raton, FL, USA, 2017 ; pp. 95-111.

78. Bodó, E.; Bíró, T.; Telek, A.; Czifra, G.; Griger, Z.; Tóth, B.I.; Mescalchin, A.; Ito, T.; Bettermann, A.; Kovács, L.; et al. A hot new twist to hair biology: Involvement of vanilloid receptor-1 (VR1/TRPV1) signaling in human hair growth control. Am. J. Pathol. 2005, 166, 985-998. [CrossRef]

79. Ständer, S.; Moormann, C.; Schumacher, M.; Buddenkotte, J.; Artuc, M.; Shpacovitch, V.; Brzoska, T.; Lippert, U.; Henz, B.M.; Luger, T.A.; et al. Expression of vanilloid receptor subtype 1 in cutaneous sensory nerve fibers, mast cells, and epithelial cells of appendage structures. Exp. Dermatol. 2004, 13, 129-139. [CrossRef] [PubMed]

80. Axelsson, H.E.; Minde, J.K.; Sonesson, A.; Toolanen, G.; Högestätt, E.D.; Zygmunt, P.M. Transient receptor potential vanilloid 1, vanilloid 2 and melastatin 8 immunoreactive nerve fibers in human skin from individuals with and without Norrbottnian congenital insensitivity to pain. Neuroscience 2009, 162, 1322-1332. [CrossRef]

81. Link, T.M.; Park, U.; Vonakis, B.M.; Raben, D.M.; Soloski, M.J.; Caterina, M.J. TRPV2 has a pivotal role in macrophage particle binding and phagocytosis. Nat. Immunol. 2010, 11, 232-239. [CrossRef] [PubMed]

82. Cheng, X.; Jin, J.; Hu, L.; Shen, D.; Dong, X.P.; Samie, M.A.; Knoff, J.; Eisinger, B.; Liu, M.L.; Huang, S.M.; et al. TRP channel regulates EGFR signaling in hair morphogenesis and skin barrier formation. Cell 2010, 141, 331-343. [CrossRef] [PubMed]

83. Denda, M.; Tsutsumi, M.; Goto, M.; Ikeyama, K.; Denda, S. Topical application of TRPA1 agonists and brief cold exposure accelerate skin permeability barrier recovery. J. Investig. Dermatol. 2010, 130, 1942-1945. [CrossRef] [PubMed]

84. Story, G.M.; Peier, A.M.; Reeve, A.J.; Eid, S.R.; Mosbacher, J.; Hricik, T.R.; Earley, T.J.; Hergarden, A.C.; Andersson, D.A.; Hwang, S.W.; et al. ANKTM1, a TRP-like channel expressed in nociceptive neurons, is activated by cold temperatures. Cell 2003, 112, 819-829. [CrossRef]

85. Tsutsumi, M.; Denda, S.; Ikeyama, K.; Goto, M.; Denda, M. Exposure to low temperature induces elevation of intracellular calcium in cultured human keratinocytes. J. Investig. Dermatol. 2010, 130, 1945-1948. [CrossRef]

86. Zappia, K.J.; Garrison, S.R.; Palygin, O.; Weyer, A.D.; Barabas, M.E.; Lawlor, M.W.; Staruschenko, A.; Stucky, C.L. Mechanosensory and ATP Release Deficits following Keratin14-Cre-Mediated TRPA1 Deletion Despite Absence of TRPA1 in Murine Keratinocytes. PLoS ONE 2016, 11, e0151602. [CrossRef] [PubMed]

87. Tóth, B.I.; Oláh, A.; Szöllősi, A.G.; Bíró, T. TRP channels in the skin. Br. J. Pharmacol. 2014, 171, 2568-2581. [CrossRef] [PubMed]

88. Ho, J.C.; Lee, C.H. TRP channels in skin: From physiological implications to clinical significances. Biophysics 2015, 11, 17-24. [CrossRef] [PubMed]

89. Brandt, E.B.; Sivaprasad, U. Th2 Cytokines and Atopic Dermatitis. J. Clin. Cell. Immunol. 2011, 2. [CrossRef] [PubMed]

90. Dhingra, N.; Shemer, A.; Correa da Rosa, J.; Rozenblit, M.; Fuentes-Duculan, J.; Gittler, J.K.; Finney, R.; Czarnowicki, T.; Zheng, $\mathrm{X} . ; \mathrm{Xu}, \mathrm{H}$.; et al. Molecular profiling of contact dermatitis skin identifies allergen-dependent differences in immune response. J. Allergy Clin. Immunol. 2014, 134, 362-372. [CrossRef]

91. Oh, M.H.; Oh, S.Y.; Lu, J.; Lou, H.; Myers, A.C.; Zhu, Z.; Zheng, T. TRPA1-dependent pruritus in IL-13-induced chronic atopic dermatitis. J. Immunol. 2013, 191, 5371-5382. [CrossRef] [PubMed]

92. Wilson, S.R.; Gerhold, K.A.; Bifolck-Fisher, A.; Liu, Q.; Patel, K.N.; Dong, X.; Bautista, D.M. TRPA1 is required for histamineindependent, Mas-related G protein-coupled receptor-mediated itch. Nat. Neurosci. 2011, 14, 595-602. [CrossRef] [PubMed]

93. Liu, T.; Ji, R.R. Oxidative stress induces itch via activation of transient receptor potential subtype ankyrin 1 in mice. Neurosci. Bull. 2012, 28, 145-154. [CrossRef]

94. Fernandes, E.S.; Vong, C.T.; Quek, S.; Cheong, J.; Awal, S.; Gentry, C.; Aubdool, A.A.; Liang, L.; Bodkin, J.V.; Bevan, S.; et al. Superoxide generation and leukocyte accumulation: Key elements in the mediation of leukotriene $B_{4}$-induced itch by transient receptor potential ankyrin 1 and transient receptor potential vanilloid 1. FASEB J. 2013, 27, 1664-1673. [CrossRef]

95. Liu, B.; Escalera, J.; Balakrishna, S.; Fan, L.; Caceres, A.I.; Robinson, E.; Sui, A.; McKay, M.C.; McAlexander, M.A.; Herrick, C.A.; et al. TRPA1 controls inflammation and pruritogen responses in allergic contact dermatitis. FASEB J. 2013, 27, 3549-3563. [CrossRef]

96. Zeng, D.; Chen, C.; Zhou, W.; Ma, X.; Pu, X.; Zeng, Y.; Zhou, W.; Lv, F. TRPA1 deficiency alleviates inflammation of atopic dermatitis by reducing macrophage infiltration. Life Sci. 2021, 266, 118906. [CrossRef]

97. Saarnilehto, M.; Chapman, H.; Savinko, T.; Lindstedt, K.; Lauerma, A.I.; Koivisto, A. Contact sensitizer 2,4-dinitrochlorobenzene is a highly potent human TRPA1 agonist. Allergy 2014, 69, 1424-1427. [CrossRef] [PubMed]

98. Wong, L.S.; Otsuka, A.; Yamamoto, Y.; Nonomura, Y.; Nakashima, C.; Kitayama, N.; Usui, K.; Honda, T.; Kabashima, K. TRPA1 channel participates in tacrolimus-induced pruritus in a chronic contact hypersensitivity murine model. J. Dermatol. Sci. 2018, 89, 207-209. [CrossRef] [PubMed]

99. Wilson, S.R.; Nelson, A.M.; Batia, L.; Morita, T.; Estandian, D.; Owens, D.M.; Lumpkin, E.A.; Bautista, D.M. The ion channel TRPA1 is required for chronic itch. J. Neurosci. 2013, 33, 9283-9294. [CrossRef] [PubMed]

100. Wilson, S.R.; Thé, L.; Batia, L.M.; Beattie, K.; Katibah, G.E.; McClain, S.P.; Pellegrino, M.; Estandian, D.M.; Bautista, D.M. The epithelial cell-derived atopic dermatitis cytokine TSLP activates neurons to induce itch. Cell 2013, 155, 285-295. [CrossRef]

101. Mishra, S.K.; Wheeler, J.J.; Pitake, S.; Ding, H.; Jiang, C.; Fukuyama, T.; Paps, J.S.; Ralph, P.; Coyne, J.; Parkington, M.; et al. Periostin Activation of Integrin Receptors on Sensory Neurons Induces Allergic Itch. Cell Rep. 2020, 31, 107472. [CrossRef] [PubMed]

102. Cevikbas, F.; Wang, X.; Akiyama, T.; Kempkes, C.; Savinko, T.; Antal, A.; Kukova, G.; Buhl, T.; Ikoma, A.; Buddenkotte, J.; et al. A sensory neuron-expressed IL-31 receptor mediates T helper cell-dependent itch: Involvement of TRPV1 and TRPA1. J. Allergy Clin. Immunol. 2014, 133, 448-460. [CrossRef] [PubMed] 
103. Boehncke, W.H.; Schön, M.P. Psoriasis. Lancet 2015, 386, 983-994. [CrossRef]

104. Szepietowski, J.C.; Reich, A. Pruritus in psoriasis: An update. Eur. J. Pain 2016, 20, 41-46. [CrossRef] [PubMed]

105. Zhang, X.; He, Y. The Role of Nociceptive Neurons in the Pathogenesis of Psoriasis. Front. Immunol. 2020, 11, 1984. [CrossRef] [PubMed]

106. Taneda, K.; Tominaga, M.; Negi, O.; Tengara, S.; Kamo, A.; Ogawa, H.; Takamori, K. Evaluation of epidermal nerve density and opioid receptor levels in psoriatic itch. Br. J. Dermatol. 2011, 165, 277-284. [CrossRef]

107. Kim, T.W.; Shim, W.H.; Kim, J.M.; Mun, J.H.; Song, M.; Kim, H.S.; Ko, H.C.; Kim, M.B.; Kim, B.S. Clinical characteristics of pruritus in patients with scalp psoriasis and their relation with intraepidermal nerve fiber density. Ann. Dermatol. 2014, 26, 727-732. [CrossRef] [PubMed]

108. Kou, K.; Nakamura, F.; Aihara, M.; Chen, H.; Seto, K.; Komori-Yamaguchi, J.; Kambara, T.; Nagashima, Y.; Goshima, Y.; Ikezawa, Z. Decreased expression of semaphorin-3A, a neurite-collapsing factor, is associated with itch in psoriatic skin. Acta Derm. Venereol. 2012, 92, 521-528. [CrossRef]

109. Cui, S.; Xiao, T.; Wang, Y.; Lu, H.; Wang, Y.; Gao, X.H.; Wei, H.; Chen, H.D. Morphological relationship between nerve fibers and Langerhans cells in the epidermis of psoriasis vulgaris and lichen simplex chronicus. J. Dermatol. Sci. 2009, 56, 132-134. [CrossRef] [PubMed]

110. Kubanov, A.A.; Katunina, O.R.; Chikin, V.V. Expression of Neuropeptides, Neurotrophins, and Neurotransmitters in the Skin of Patients with Atopic Dermatitis and Psoriasis. Bull. Exp. Biol. Med. 2015, 159, 318-322. [CrossRef]

111. Jiang, W.Y.; Raychaudhuri, S.P.; Farber, E.M. Double-labeled immunofluorescence study of cutaneous nerves in psoriasis. Int. J. Dermatol. 1998, 37, 572-574. [CrossRef] [PubMed]

112. Reich, A.; Orda, A.; Wiśnicka, B.; Szepietowski, J.C. Plasma concentration of selected neuropeptides in patients suffering from psoriasis. Exp. Dermatol. 2007, 16, 421-428. [CrossRef]

113. Ostrowski, S.M.; Belkadi, A.; Loyd, C.M.; Diaconu, D.; Ward, N.L. Cutaneous denervation of psoriasiform mouse skin improves acanthosis and inflammation in a sensory neuropeptide-dependent manner. J. Investig. Dermatol. 2011, 131, 1530-1538. [CrossRef] [PubMed]

114. Zhou, Y.; Han, D.; Follansbee, T.; Wu, X.; Yu, S.; Wang, B.; Shi, Z.; Domocos, D.T.; Carstens, M.; Carstens, E.; et al. Transient receptor potential ankyrin 1 (TRPA1) positively regulates imiquimod-induced, psoriasiform dermal inflammation in mice. J. Cell. Mol. Med. 2019, 23, 4819-4828. [CrossRef] [PubMed]

115. Nattkemper, L.A.; Tey, H.L.; Valdes-Rodriguez, R.; Lee, H.; Mollanazar, N.K.; Albornoz, C.; Sanders, K.M.; Yosipovitch, G. The Genetics of Chronic Itch: Gene Expression in the Skin of Patients with Atopic Dermatitis and Psoriasis with Severe Itch. J. Investig. Dermatol. 2018, 138, 1311-1317. [CrossRef] [PubMed]

116. Kemény, Á.; Kodji, X.; Horváth, S.; Komlódi, R.; Szőke, É.; Sándor, Z.; Perkecz, A.; Gyömörei, C.; Sétáló, G.; Kelemen, B.; et al. TRPA1 Acts in a Protective Manner in Imiquimod-Induced Psoriasiform Dermatitis in Mice. J. Investig. Dermatol. 2018, 138, 1774-1784. [CrossRef]

117. Yang, R.; Zhou, Q.; Wen, C.; Hu, J.; Li, H.; Zhao, M.; Zhao, H. Mustard seed (Sinapis Alba Linn) attenuates imiquimod-induced psoriasiform inflammation of BALB/c mice. J. Dermatol. 2013, 40, 543-552. [CrossRef] [PubMed]

118. Jawed, S.I.; Myskowski, P.L.; Horwitz, S.; Moskowitz, A.; Querfeld, C. Primary cutaneous T-cell lymphoma (mycosis fungoides and Sézary syndrome): Part II. Prognosis, management, and future directions. J. Am. Acad. Dermatol. 2014, 70, 223.e1-223.e17. [CrossRef] [PubMed]

119. Furue, M.; Kadono, T. New therapies for controlling atopic itch. J. Dermatol. 2015, 42, 847-850. [CrossRef] [PubMed]

120. Miyagaki, T.; Sugaya, M. Immunological milieu in mycosis fungoides and Sézary syndrome. J. Dermatol. 2014, 41, 11-18. [CrossRef]

121. Han, Q.; Liu, D.; Convertino, M.; Wang, Z.; Jiang, C.; Kim, Y.H.; Luo, X.; Zhang, X.; Nackley, A.; Dokholyan, N.V.; et al. miRNA-711 Binds and Activates TRPA1 Extracellularly to Evoke Acute and Chronic Pruritus. Neuron 2018, 99, 449-463.e446. [CrossRef] [PubMed]

122. Chosidow, O. Clinical practices. Scabies. N. Engl. J. Med. 2006, 354, 1718-1727. [CrossRef]

123. Sanders, K.M.; Nattkemper, L.A.; Rosen, J.D.; Andersen, H.H.; Hsiang, J.; Romanelli, P.; Bernigaud, C.; Guillot, J.; Chosidow, O.; Yosipovitch, G. Non-Histaminergic Itch Mediators Elevated in the Skin of a Porcine Model of Scabies and of Human Scabies Patients. J. Investig. Dermatol. 2019, 139, 971-973. [CrossRef] [PubMed]

124. Lieu, T.; Jayaweera, G.; Zhao, P.; Poole, D.P.; Jensen, D.; Grace, M.; McIntyre, P.; Bron, R.; Wilson, Y.M.; Krappitz, M.; et al. The bile acid receptor TGR5 activates the TRPA1 channel to induce itch in mice. Gastroenterology 2014, 147, 1417-1428. [CrossRef]

125. Hashimoto, T.; Kursewicz, C.D.; Fayne, R.A.; Nanda, S.; Shah, S.M.; Nattkemper, L.; Yokozeki, H.; Yosipovitch, G. Pathophysiologic mechanisms of itch in bullous pemphigoid. J. Am. Acad. Dermatol. 2020, 83, 53-62. [CrossRef]

126. Yang, Y.S.; Cho, S.I.; Choi, M.G.; Choi, Y.H.; Kwak, I.S.; Park, C.W.; Kim, H.O. Increased expression of three types of transient receptor potential channels (TRPA1, TRPV4 and TRPV3) in burn scars with post-burn pruritus. Acta Derm. Venereol. 2015, 95, 20-24. [CrossRef] [PubMed]

127. Obata, K.; Katsura, H.; Mizushima, T.; Yamanaka, H.; Kobayashi, K.; Dai, Y.; Fukuoka, T.; Tokunaga, A.; Tominaga, M.; Noguchi, K. TRPA1 induced in sensory neurons contributes to cold hyperalgesia after inflammation and nerve injury. J. Clin. Investig. 2005, 115, 2393-2401. [CrossRef] [PubMed]

128. Caspani, O.; Zurborg, S.; Labuz, D.; Heppenstall, P.A. The contribution of TRPM8 and TRPA1 channels to cold allodynia and neuropathic pain. PLoS ONE 2009, 4, e7383. [CrossRef] 
129. Eid, S.R.; Crown, E.D.; Moore, E.L.; Liang, H.A.; Choong, K.C.; Dima, S.; Henze, D.A.; Kane, S.A.; Urban, M.O. HC-030031, a TRPA1 selective antagonist, attenuates inflammatory- and neuropathy-induced mechanical hypersensitivity. Mol. Pain 2008, 4, 1744-8069. [CrossRef] [PubMed]

130. Moilanen, L.J.; Laavola, M.; Kukkonen, M.; Korhonen, R.; Leppänen, T.; Högestätt, E.D.; Zygmunt, P.M.; Nieminen, R.M.; Moilanen, E. TRPA1 contributes to the acute inflammatory response and mediates carrageenan-induced paw edema in the mouse. Sci. Rep. 2012, 2, 380. [CrossRef] [PubMed]

131. Marone, I.M.; De Logu, F.; Nassini, R.; De Carvalho Goncalves, M.; Benemei, S.; Ferreira, J.; Jain, P.; Li Puma, S.; Bunnett, N.W.; Geppetti, P.; et al. TRPA1/NOX in the soma of trigeminal ganglion neurons mediates migraine-related pain of glyceryl trinitrate in mice. Brain 2018, 141, 2312-2328. [CrossRef] [PubMed]

132. Nassini, R.; Materazzi, S.; Vriens, J.; Prenen, J.; Benemei, S.; De Siena, G.; la Marca, G.; Andrè, E.; Preti, D.; Avonto, C.; et al. The 'headache tree' via umbellulone and TRPA1 activates the trigeminovascular system. Brain 2012, 135, 376-390. [CrossRef]

133. Antoniazzi, C.T.D.; Nassini, R.; Rigo, F.K.; Milioli, A.M.; Bellinaso, F.; Camponogara, C.; Silva, C.R.; de Almeida, A.S.; Rossato, M.F.; De Logu, F.; et al. Transient receptor potential ankyrin 1 (TRPA1) plays a critical role in a mouse model of cancer pain. Int. J. Cancer 2019, 144, 355-365. [CrossRef]

134. Glenmark, P. A Clinical Trial to Study the Effects GRC 17536 in Patients with Painful Diabetic Peripheral Neuropathy (Painful Extremities Due to Peripheral Nerve Damage in Diabetic Patients). Available online: https:/ /ClinicalTrials.gov/show/NCT017 26413 (accessed on 26 February 2021).

135. Cubist Pharmaceuticals and Hydra Biosciences Announce Plans to Begin Phase 1 Clinical Trial for Novel TRPA1 Modulator to Treat Acute. Available online: http://hydrabiosciences.com/pdf/press_releases/2012_01_10.pdf (accessed on 26 February 2021).

136. Hydra Biosciences Receives Approval from Health Canada to Begin Phase 1 Trial for HX-100. Available online: http:// hydrabiosciences.com/pdf/press_releases/2015_04_14.pdf (accessed on 26 February 2021).

137. Orion, C. Safety, Tolerability, Pharmacokinetic and Pharmacodynamic Effects of ODM-108: In Healthy Male Volunteers. Available online: https://ClinicalTrials.gov/show / NCT02432664 (accessed on 26 February 2021).

138. Genentech, I. A Study of the Safety, Tolerability, Pharmacokinetics and Pharmacodynamic Effects of Single and Multiple Ascending Doses of GDC-0334 and the Effect of Food on the Pharmacokinetics of GDC-0334 in Healthy Adult Participants. Available online: https:/ /ClinicalTrials.gov/show / NCT03381144 (accessed on 26 February 2021).

139. Chen, H.; Terrett, J.A. Transient receptor potential ankyrin 1 (TRPA1) antagonists: A patent review (2015-2019). Expert Opin. Ther. Pat. 2020, 30, 643-657. [CrossRef] [PubMed]

140. Bressan, E.; Touska, F.; Vetter, I.; Kistner, K.; Kichko, T.I.; Teixeira, N.B.; Picolo, G.; Cury, Y.; Lewis, R.J.; Fischer, M.J.M.; et al Crotalphine desensitizes TRPA1 ion channels to alleviate inflammatory hyperalgesia. Pain 2016, 157, 2504-2516. [CrossRef]

141. Kortekaas Krohn, I.; Callebaut, I.; Alpizar, Y.A.; Steelant, B.; Van Gerven, L.; Skov, P.S.; Kasran, A.; Talavera, K.; Wouters, M.M.; Ceuppens, J.L.; et al. MP29-02 reduces nasal hyperreactivity and nasal mediators in patients with house dust mite-allergic rhinitis. Allergy 2018, 73, 1084-1093. [CrossRef] [PubMed]

142. Benemei, S.; De Logu, F.; Li Puma, S.; Marone, I.M.; Coppi, E.; Ugolini, F.; Liedtke, W.; Pollastro, F.; Appendino, G.; Geppetti, P.; et al. The anti-migraine component of butterbur extracts, isopetasin, desensitizes peptidergic nociceptors by acting on TRPA1 cation channel. Br. J. Pharmacol. 2017, 174, 2897-2911. [CrossRef]

143. Materazzi, S.; Benemei, S.; Fusi, C.; Gualdani, R.; De Siena, G.; Vastani, N.; Andersson, D.A.; Trevisan, G.; Moncelli, M.R.; Wei, X.; et al. Parthenolide inhibits nociception and neurogenic vasodilatation in the trigeminovascular system by targeting the TRPA1 channel. Pain 2013, 154, 2750-2758. [CrossRef] [PubMed]

144. Gautier, M.; Dhennin-Duthille, I.; Ay, A.S.; Rybarczyk, P.; Korichneva, I.; Ouadid-Ahidouch, H. New insights into pharmacological tools to TR(i)P cancer up. Br. J. Pharmacol. 2014, 171, 2582-2592. [CrossRef] [PubMed]

145. Lehen'kyi, V.Y.; Prevarskaya, N. Oncogenic TRP Channels. In Transient Receptor Potential Channels; Islam, M.S., Ed.; Springer: Dordrecht, The Netherlands, 2011; pp. 929-945.

146. Zheng, J.; Liu, F.; Du, S.; Li, M.; Wu, T.; Tan, X.; Cheng, W. Mechanism for Regulation of Melanoma Cell Death via Activation of Thermo-TRPV4 and TRPV2. J. Oncol. 2019, 2019, 7362875. [CrossRef] [PubMed]

147. Brusco, I.; Li Puma, S.; Chiepe, K.B.; da Silva Brum, E.; de David Antoniazzi, C.T.; de Almeida, A.S.; Camponogara, C.; Silva, C.R.; De Logu, F.; de Andrade, V.M.; et al. Dacarbazine alone or associated with melanoma-bearing cancer pain model induces painful hypersensitivity by TRPA1 activation in mice. Int. J. Cancer 2020, 146, 2797-2809. [CrossRef] [PubMed]

148. Fink, C.; Uhlmann, L.; Enk, A.; Gholam, P. Pain management in photodynamic therapy using a nitrous oxide/oxygen mixture: A prospective, within-patient, controlled clinical trial. J. Eur. Acad. Dermatol. Venereol. 2017, 31, 70-74. [CrossRef] [PubMed]

149. Maglie, R.; Antiga, E.; Payne, A.S. B-cell targeted therapies in pemphigus. G. Ital. Dermatol. Venereol. 2020. [CrossRef]

150. Gao, S.; Kaudimba, K.K.; Guo, S.; Zhang, S.; Liu, T.; Chen, P.; Wang, R. Transient Receptor Potential Ankyrin Type-1 Channels as a Potential Target for the Treatment of Cardiovascular Diseases. Front. Physiol. 2020, 11, 836. [CrossRef] [PubMed]

151. Guo, Y.; Ying, S.; Zhao, X.; Liu, J.; Wang, Y. Increased expression of lung TRPV1/TRPA1 in a cough model of bleomycin-induced pulmonary fibrosis in Guinea pigs. BMC Pulm. Med. 2019, 19, 27. [CrossRef] [PubMed] 